\title{
METAMORPHOSIS VISUALIZATION WITH AUGMENTED REALITY USING MARKER-BASED TRACKING
}

\author{
Bayu Bagus Kencana1, Muhammad Fathur Prayudha², Budi Arifitama ${ }^{3}$ \\ Program Studi Teknik Informatika \\ Universitas Trilogi \\ bagus.bayu@trilogi.ac.id,faturprayuda@trilogi.ac.id,budiarif@trilogi.ac.id
}

\begin{abstract}
Abstrak
Metamorfosis adalah siklus perkembangan biologis dari pertumbuhan hewan mulai dari penetasan hingga mengalami perubahan. Siklus metamorfosis dipelajari dalam pembelajaran untuk siswa di sekolah pada mata pelajaran Biologi. Sayangnya untuk dapat melihat interaksi siklus metamorfosis hewan, membutuhkan waktu dan menemukan hewan yang ingin diamati. Penelitian ini memberikan solusi inovatf dalam menjawab permasalahan yaotu dengan menggunakan augmented reality. Teknologi augmented reality memvisualisasikan proses metamorfosis dari hewan kedalam bentuk 4 dimensi sehingga siswa menjadi antusias untuk mempelajari bagaimana proses metamorfosis perubahan hewan. Metode Marker-Based Tracking digunakan sebagai pendekatan penyelesaian permasalahan dimana lokasi pola tracking pada marker telah ditentukan terlebih dahulu sebagai tempat kemunculan objek augmented reality. Hasil dari penelitian ini menunjukan bahwa dengan menggunakan metode marker-based tracking pembelajaran metamorfosis hewan dapat meningkatkan pemahaman metamorfosis siswa karena lebih interaktif.
\end{abstract}

Kata kunci: Augmented Reality, Metamorfosis, Marker-Based Tracking

\begin{abstract}
Metamorphosis is a cycle of biological animal growth. Learning Metamorphosis is a part of learning for students in schools specifically in the area of biology subjects. Unfortunately, the observing activities take time, and finding an animal specimen is limited to study the metamorphosis cycle. This research proposes an innovative solution to overcome these problems which is the implementation of augmented reality technology. The animal metamorphosis cycle process is visualized into 4-dimensional objects to improve interaction for the student on learning metamorphosis during learning sessions. The Marker-Based Tracking method is used as an approach where the location of the tracking pattern on the marker has been determined in advance as the place where the augmented reality object appears. The results of this study indicate that using a marker-based tracking method can improve students' understanding of metamorphosis.
\end{abstract}

Keywords: Augmented Reality, Metamorphosis, Marker-Based Tracking

\section{INTRODUCTION}

Metamorphosis is a physical-biological development process of an animal from birth or hatching to develop into a new form physically. The process that occurs in a complete metamorphosis will experience four stages of growth, starting with eggs, larvae, pupa, and adults, while incomplete metamorphosis undergoes three stages of growth starting with eggs, nymphs, and adults (Truman \& Riddiford, 2019),(Gonzalez, Jiang, \& Lowe, 2018),(Hammer, McMillan, \& Fierer, 2014) of learning to recognize the process of animal change is important for a student, especially in biology subject. The process of learning until now uses video learning media to learn biology (Nur \& Nurdiana, 2019) and resulted in an improvement in cognitive learning for the student, but lack of interaction between the video and the student. Textbooks are also used as an approach for learning biology in school (WP \& Supen0, 2018), the approach using textbook on students for biology learning has been analyzed (Cimer \& Coskun, 2018) and resulted that textbooks are still effective for knowledge transfer but lacks the interaction on the student still resulted in a 
problem for improving the learning process of the student. The lack of interaction using books and video learning media from previous research stated makes the learning process less attractive to the student. This research proposes a solution to the problem stated, using augmented reality technology. The use of Augmented Reality technology for introducing metamorphosis is expected to develop a more attractive and interactive learning process about learning how animal processes can carry out a process of perfect and imperfect metamorphosis. Augmented Reality is a term to describe the real and virtual world combined to create the illusion that there is no boundary between them (Arifitama \& Syahputra, 2017),(Ibáñez \& Delgado-Kloos, 2018). Augmented Reality technology makes $3 d$ objects that have been created appear to be real(Lee, 2012). This technology combines the existing environment in the real world and runs interactively in real-time and creates a mixture between components to be used in three-dimensional media for information and promotion facilities (Syahputra \& Arifitama, 2018). Marker-Based Tracking is used as a marker in this research. Marker-Based Tracking requires a two-dimensional marker that has a unique pattern that will be read by a computer through the camera(Gherghina, Olteanu, \& Tapus, 2013),(Perwitasari, 2018). Users will use a predetermined pattern to be able to display objects and be able to interact with the user through the device. The appearance of animal objects will make students understand how to distinguish between perfect and imperfect metamorphosis change processes. The result of this research that the application of the introduction of the perfect and imperfect metamorphosis process through augmented reality with the marker-based tracking method can help education personnel explain about metamorphosis in a more attractive learning process for the student to understand more clearly.

\section{RESEARCH METHODS}

The method used in this research is using the marker-based tracking method(Siltanen, 2012). (Fleck, Hachet, \& Bastien, 2015). The implementation of the Marker-Based Tracking method in Augmented Reality requires an image that has a unique pattern to display objects, shown in Figure 1.
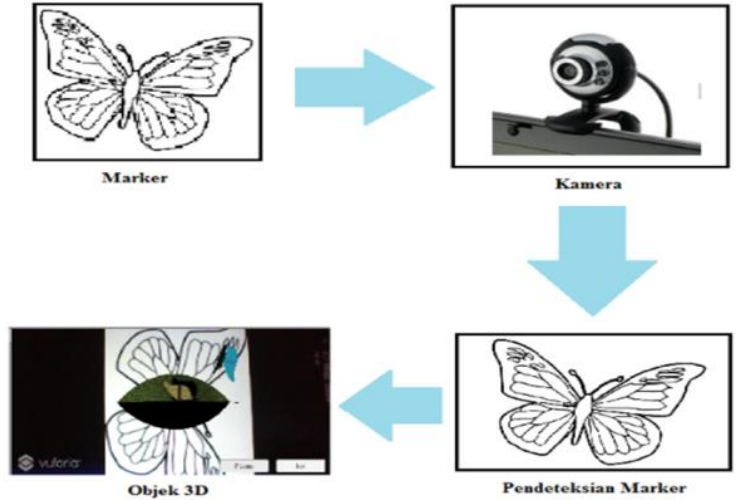

Figure 1. Marker Based Tracking Mechanism

From the image shown in Figure 1, the camera will scan the marker created and detected, the desired augmented reality object will appear. The development of augmented reality consists of several development phases which are 3D object design, Software Development, and Augmented reality marker development which uses supporting software namely.

\section{SketchUp Software}

SketchUp is a 3D modeling application that is used for various depictions such as architecture, interior design, video games, and film design (Lewis \& Hampton, 2015). In this research, Sketchup is used to create object models for metamorphosis materials as showed in Figure 2.

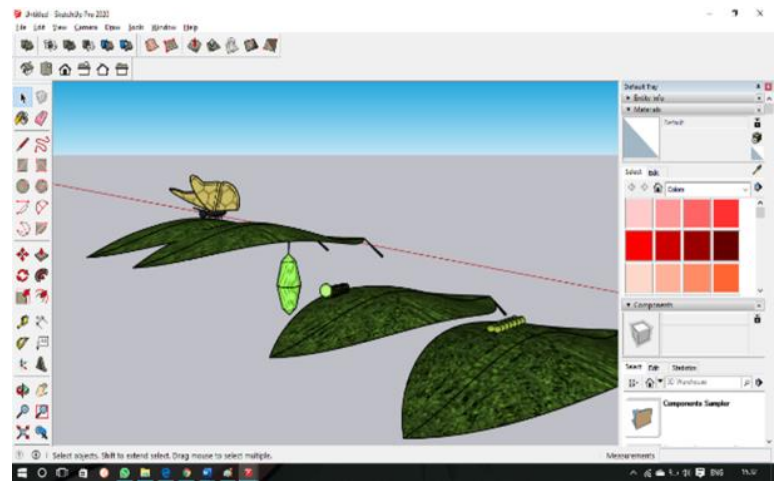

Figure 2. 3D Metamorphosis Object Modeling

\section{Unity 3D Platform}

Unity $3 D$ is an integrated multi-platform game development technology for game creation(Unity Technology, 2018), building architecture, and simulation. Therefore, this study uses Unity to design the display navigation, shown in Figure 3. 
JURNAL RISET INFORMATIKA

Vol. 3, No. 1 December 2020

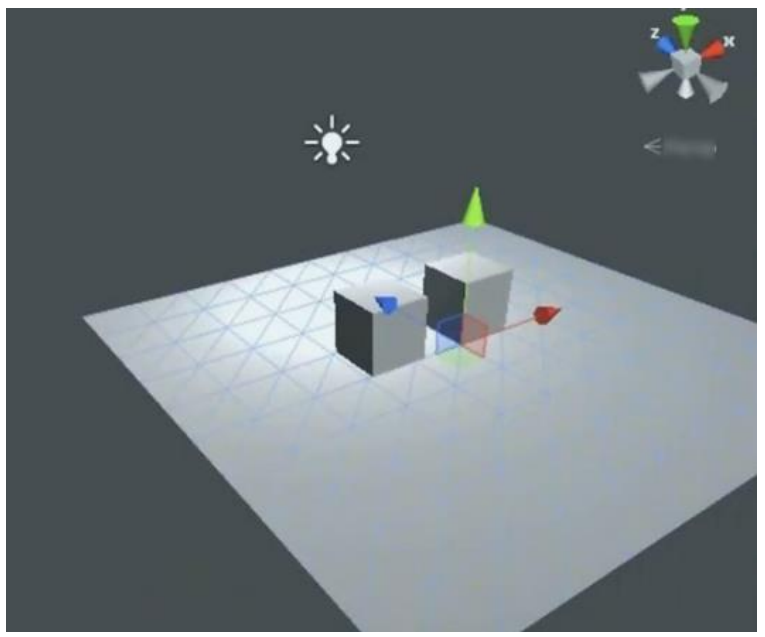

Figure 3. Unity Platform

\section{Vuforia Software Development Kit}

Vuforia or Vuforia SDK (Software Development Kit) is a library for building Augmented Reality applications(Simonetti, Alexandro; Paredes, 2016). To integrate it requires a marker that has been stored in the Vuforia database.

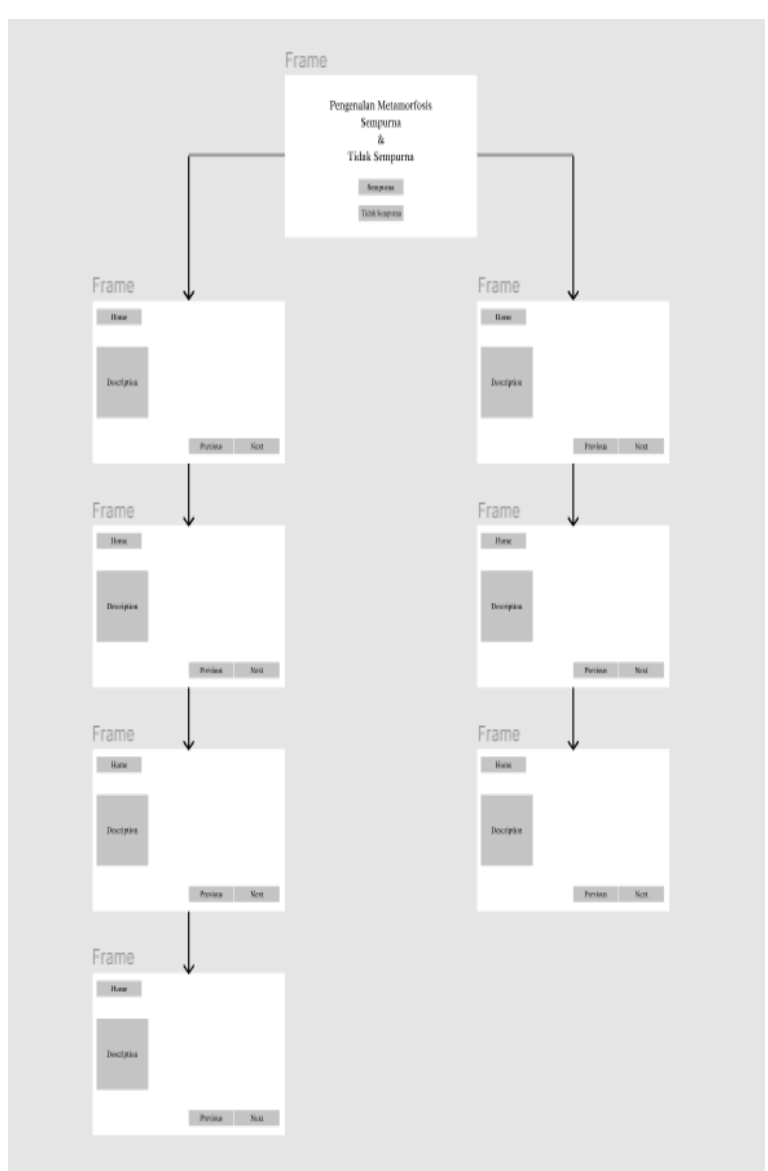

Figure 4. Hierarchy of Application Display Design
P-ISSN: 2656-1743 |E-ISSN: 2656-1735 DOI: https://doi.org/10.34288/jri.v3i1.168

Hierarchy is a sequence between components that describes how the system is connected. With this hierarchy, the application display will be seen where on the top frame is the main page which has two menus, namely the perfect menu which will display perfect metamorphosis and has 4 frames and an imperfect menu that will display imperfect metamorphosis which has 3 frames.

\section{RESULT AND DISCUSSION}

\section{Augmented Reality Implementation}

Vuforia Software Development Kit (SDK) is used to create marker-based tracking and to test the accuracy and accuracy of markers. The image that is used as a marker in this research is shown in Figures 5 and 6.

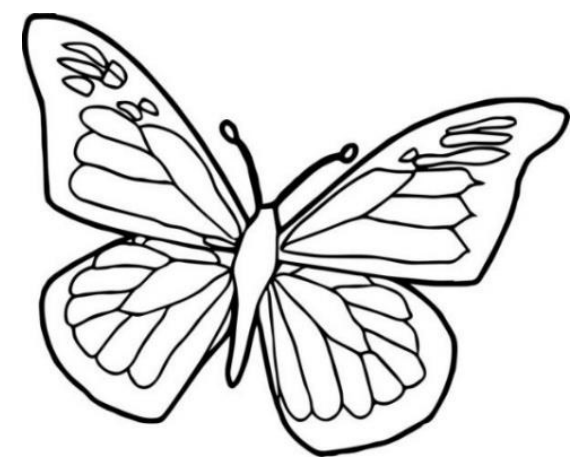

Figure 5. Perfect Metamorphosis Augmented Reality Marker

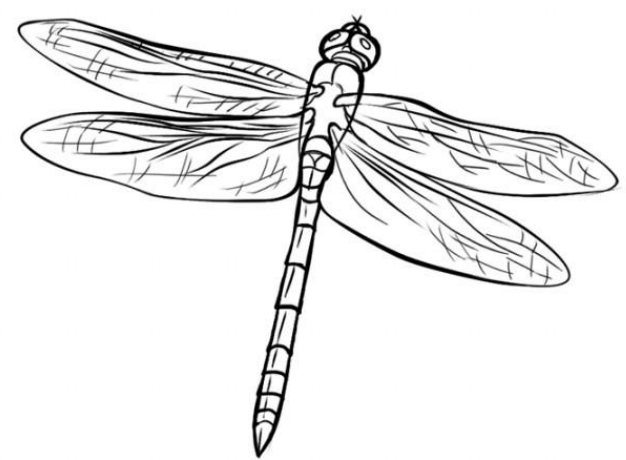

Figure 6. Incomplete Metamorphosis Augmented Reality Marker

It can be seen in Figures 5 and 6 that each marker has a unique pattern that differentiates it from other patterns as a basic marker pattern used for augmented reality. The results obtained through Vuforia are that the markers used have a pattern that can be applied to Augmented Reality with a value of 5 out of 5 and can be seen in Figures 7 and 8. 


\author{
Type: Single Image \\ Status: Active \\ Target ID: 2fbc48b3c41e47e79051699b85c2be48 \\ Augmentable: $x+1 \times 1$ \\ Added: May 27, 2020 19:15 \\ Modified: May 27, 2020 19:15
}

Figure 7. Marker Value for Perfect Metamorphosis

\author{
Type: Single Image \\ Status: Active \\ Target ID: 35edd82c27424281ac496e70fcd445bb

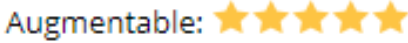 \\ Added: May 27, 2020 19:15 \\ Modified: May 27, $202019: 15$
}

Figure 8. Incomplete Metamorphosis Marker Value

The chosen markers are imported to Unity for the application development process that has been integrated with Vuforia, to implement the perfect and imperfect metamorphosis process application showed in Figure 9.

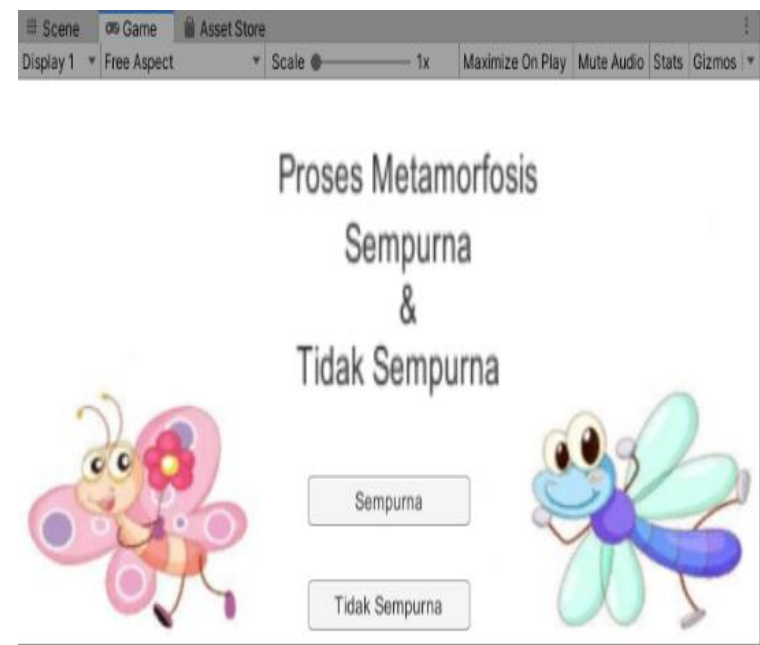

Figure 9. Initial Appearance

This initial display will direct the user to the perfect and imperfect metamorphosis menu. When the user clicks the Perfect Metamorphosis button, will be directed into another scene shown in Figure 10.

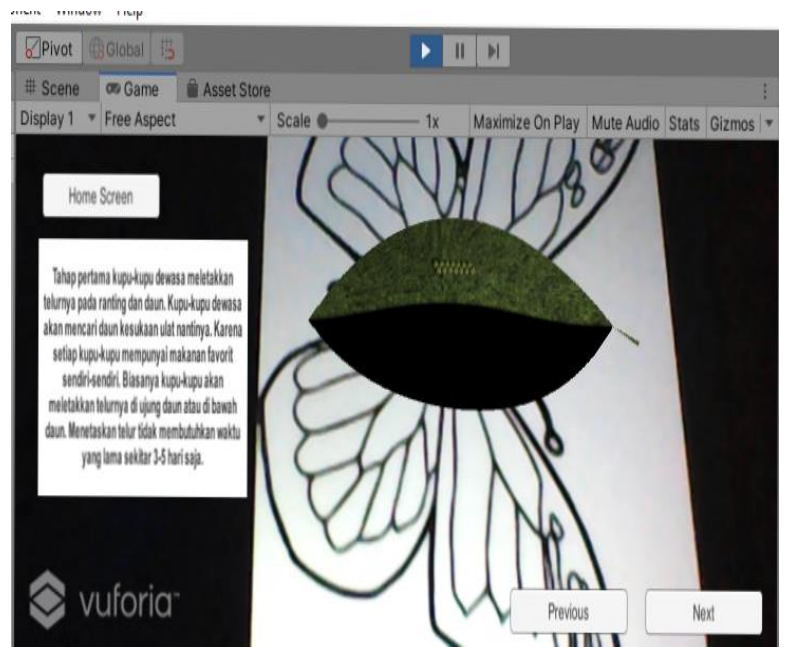

Figure 10. Display of the First Process of Complete Metamorphosis

The computer will turn on the camera where the camera will scan the markers that have been prepared, then the 3D Augmented Reality object consisting of butterfly eggs and leaves. Next to the object, a description of the phase that occurs in the object will appear. When the user clicks the Home Screen button, the user will go back to the main menu shown in Figure 9. When the user clicks the next button, the object will change when the user scans the same marker as shown in Figure 11 or when the previous button is clicked, the object will appear in Figure 13.

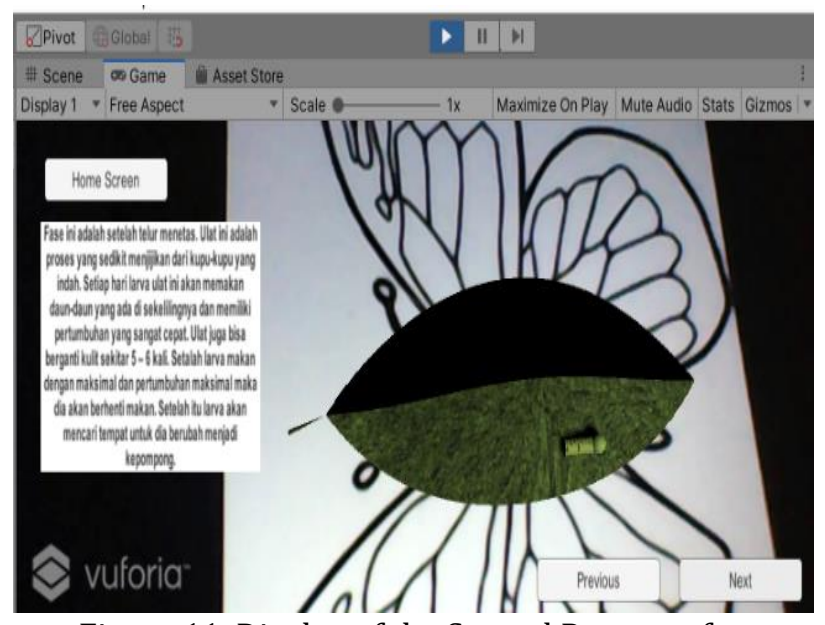

Figure 11. Display of the Second Process of Complete Metamorphosis

In figure 11, the object will change from an egg to a larva. There is a description that explains the larval phase in an object. When the user clicks the next button, the object will change to the next phase in Figure 12 or when the user clicks the previous button the object will appear in Figure 10. 


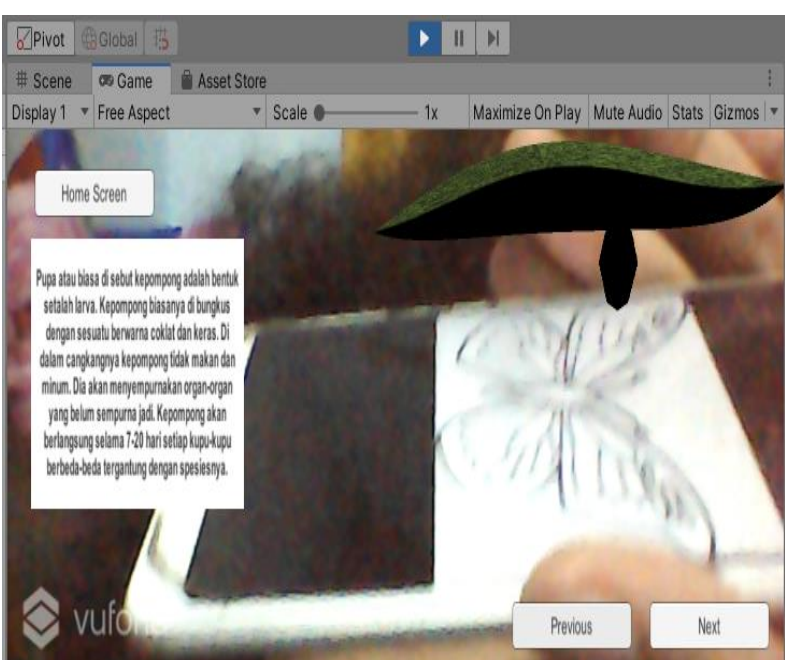

Figure 12. Display of the Third Process of Complete Metamorphosis

In figure 12, shows the process of changing from a larva into a cocoon. There is a description that explains the cocoon phase. When the user clicks the next button, the object will change to the next phase in Figure 13.

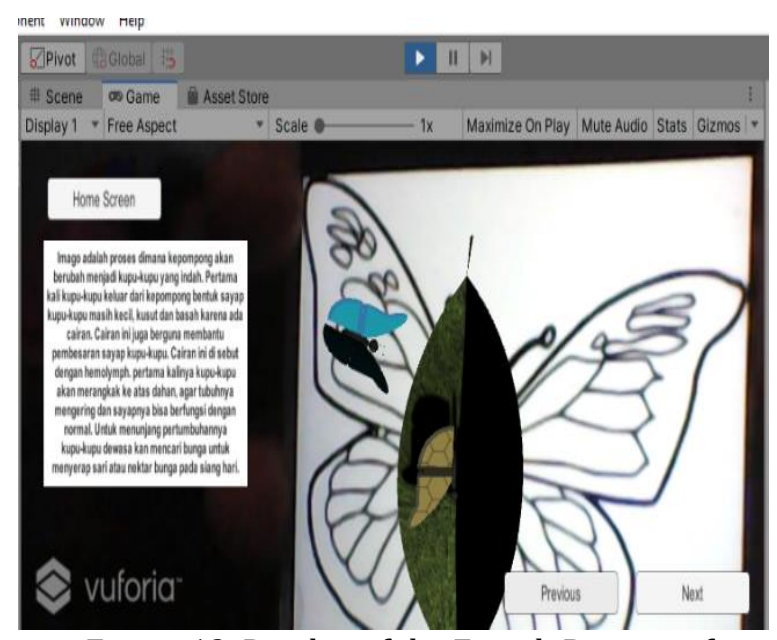

Figure 13. Display of the Fourth Process of Complete Metamorphosis

In figure 13, shows the final process of metamorphosis which is a butterfly. There is a description that explains the final phase.

\section{Software Usability Testing}

Software testing is needed as a form of validation regarding the effectiveness of the research. Researchers conducted test case validation by distributing test case sheets to 5 application developers. The test case results are as follows :
Table 1. Usability Testing

\begin{tabular}{clc}
\hline No & \multicolumn{1}{c}{ Usability Test Case } & Average Result \\
\hline 1 & $\begin{array}{l}\text { Testing movement scene } \\
\text { link }\end{array}$ & 80 \\
2 & $\begin{array}{l}\text { Testing the quality of object } \\
\text { detection }\end{array}$ & 90 \\
3 & $\begin{array}{l}\text { Testing the stability of } \\
\text { object detection }\end{array}$ & 90 \\
4 & User Interface Design & 70 \\
5 & Object Visibility & 90 \\
6 & Object Detection Time & 80 \\
& Responses & 80 \\
7 & Object Detection Accuracy & 70 \\
8 & User Interface Color & \\
$\quad$ management & 80 \\
9 & Detailed Augmented Object & 70 \\
10 & Installation Application & \\
$\quad$ Responses & Total Average \\
\hline \multicolumn{2}{c}{}
\end{tabular}

Based on the results of usability testing performed by the software developer, the average acceptance score is 80 , where this value can be concluded that the application is ready for the user.

\section{CONCLUSIONS AND SUGGESTIONS}

\section{Conclusions}

Based on the result, augmented reality can be used to visualize and help educators in explaining the perfect and imperfect of animals' metamorphosis to the student in a more attractive way. The marker-based tracking used in this research is compatible to be used as a marker.

\section{Suggestions}

The suggestions that can be performed for future research are to animate the $3 \mathrm{~d}$ objects to make it more interactive, The use of different marker like markerless-based tracking to further understand which type of marker is more compatible.

\section{REFERENCE}

Arifitama, B., \& Syahputra, A. (2017). Cultural Heritage Digitalization on Traditional Sundanese Music Instrument Using Augmented Reality Markerless Marker Method. Jurnal Teknologi Dan Sistem Komputer.

https://doi.org/10.14710/jtsiskom.5.3.2017. 101-105

Cimer, A., \& Coskun, S. (2018). Students' Opinions about Their Ninth Grade Biology Textbook: From the Perspective of Constructivist 
Learning Approach. Journal of Education and Learning. https://doi.org/10.5539/jel.v7n4p201

Fleck, S., Hachet, M., \& Bastien, J. M. C. (2015). Marker-based augmented reality. https://doi.org/10.1145/2771839.2771842

Gherghina, A., Olteanu, A. C., \& Tapus, N. (2013). A marker-based augmented reality system for mobile devices. Proceedings - RoEduNet IEEE International Conference. https://doi.org/10.1109/RoEduNet.2013.65 11731

Gonzalez, P., Jiang, J. Z., \& Lowe, C. J. (2018). The development and metamorphosis of the indirect developing acorn worm Schizocardium californicum (Enteropneusta: Spengelidae). Frontiers in Zoology. https://doi.org/10.1186/s12983-018-02700

Hammer, T. J., McMillan, W. O., \& Fierer, N. (2014). Metamorphosis of a butterfly-associated bacterial community. PLOS ONE. https://doi.org/10.1371/journal.pone.00869 95

Ibáñez, M. B., \& Delgado-Kloos, C. (2018). Augmented reality for STEM learning: A systematic review. Computers and Education. https://doi.org/10.1016/j.compedu.2018.05. 002

Lee, K. (2012). Augmented Reality in Education and Training. TechTrends. https://doi.org/10.1007/s11528-012-05593

Lewis, G. M., \& Hampton, S. J. (2015). Visualizing volcanic processes in SketchUp: An integrated geo-education tool. Computers and Geosciences.

https://doi.org/10.1016/j.cageo.2015.05.003

Nur, B., \& Nurdiana, S. (2019). Video Based Learning sebagai Media Belajar Biologi Jarak Jauh Masa Kini Video-Based Learning as a
Present Distance Learning Biology Media. In Seminar Nasional Biologi dan Pembelajarannya Universitas Negeri Makassar.

Perwitasari, I. D. (2018). Teknik Marker Based Tracking Augmented Reality untuk Visualisasi Anatomi Organ Tubuh Manusia Berbasis Android. INTECOMS: Journal of Information Technology and Computer Science. https://doi.org/10.31539/intecoms.v1i1.161

Siltanen, S. (2012). Theory and applications of marker-based augmented reality. In Espoo 2012. VTT Science Series 3.

Simonetti, Alexandro;Paredes, J. (2016). Vuforia v1.5 SDK: Analysis and evaluation of capabilities.

Syahputra, A., \& Arifitama, B. (2018). PENGEMBANGAN ALAT PERAGA EDUKASI PROSES SIKLUS AIR (HIDROLOGI) MENGGUNAKAN TEKNOLOGI AUGMENTED REALITY. Seminar Nasional Teknologi Dan Multimedia (SEMNASTEKNOMEDIA), 2-11-1.

Truman, J. W., \& Riddiford, L. M. (2019). The evolution of insect metamorphosis: A developmental and endocrine view. Philosophical Transactions of the Royal Society B: $\quad$ Biological Sciences. https://doi.org/10.1098/rstb.2019.0070

Unity Technology. (2018). Unity 3D. In Unity Technology.

WP, H., \& SupenO, D. (2018). THE EFFECTIVINESS OF BIOLOGY TEXTBOOK-BASED MNEMONIC STRATEGIES-ASSISTED METHOD MIND MAPPING AGAINST LEARNING RETENTION OF STUDENTS TO THE STUDY OF BIOLOGY IN SENIOR HIGH SCHOOL. International Journal of Advanced Research. https://doi.org/10.21474/ijar01/6977 